\title{
HAK-HAK PEREMPUAN MENURUT PERSPEKTIF AL-QURAN
}

\author{
Nurhayati B \\ UIN Suska Riau, Indonesia \\ nurhayati.b@uin-suska.ac.id \\ Mal Al Fahnum \\ Unindra PGRI Jakarta, Indonesia \\ mal.alfahnum@gmail.com
}

\begin{abstract}
Islamic teachings essentially do not distinguish between the rights of women and men in married life and in social life. In the Qur'an many meet in verses about respect for women's rights. By doing a textual interpretation it can be seen that women also have rights as men, although on certain matters there are not the same, this is due to the main functions and duties that in men.

In Islam women also have rights as men, but in certain cases there are not the same, this is due to the main functions and tasks held by men. Among the rights of women are: the right to get an education, the right to get a dowry and a living, the right to ask for divorce when sufficient conditions and if passed will cause harm, rights in the field of inheritance and material rights.
\end{abstract}

Keywords: Understanding the Quran, Women's Rights, Textual Interpretation

\section{ABSTRAK}

Ajaran Islam hakikatnya tidak membedakan antara bake perempuan dan laki-laki dalam kehidupan berumahtangga maupun dalam kehidupan bermasyarakat. Dalam Al-quran banyak di temui ayat-ayat tentang penghormatan atas hak perempuan tersebut. Dengan melakukan penafsiran secara textual dapat dilihat bahwa perempuan juga mempunyai hak sebagaimana kaum laki laki, kendati pada bal-bal tertentu ada yang tidak sama, hal ini di sebabkan fungsi dan tugas utama yang di emban kaum laki-laki.

Dalam islam perempuan juga mempunyai hak sebagaimana kaum laki-laki, namun pada hal-hal tertentu ada yang tidak sama, hal ini disebabkan fungsi dan tugas utama yang diemban kaum laki-laki. Diantara bak-hak perempuan itu adalab: hak mendapatkan pendidikan, hak mendapatkan mahar dan nafkah, hak minta cerai apabila telab cukup syarat-syaratnya dan kalau diteruskan akan menimbulkan kemudharatan, bak dalam bidang kewarisan dan hak materi.

Kata Kunci: Memahami Al-Quran, Hak-bak Perempuan, Penafsiran Textual 


\section{A. PENDAHULUAN}

Laki-laki dan perempuan pada dasarnya makhluk ciptaan Allah yang diikuti dengan hak dan kewajian masing-masing. Sebagai makhluk potensil dalam proses kehidupannya laki-laki dan perempuan memiliki kemampuan untuk menempatkan dirinya pada posisi tertentu yang secara sosial religius keberadaannya diakui oleh yang lain. Akan tetapi dinamika sosial tidak selalu memiliki cara pandang yang sama dalam memahami hak terutama hak-hak pada perempuan. Bias cara pandang sosial budaya banyak mempengaruhi cara pandang dalam memahami agama termasuk dalam memahami al Qur'an sehingga sering menimbulkan dampak yang terkesan merendahkan atau bahkan membatasi peran perempuan.

Islam hakikatnya adalah agama prinsip yang menjelaskan aturan-aturan baku yang wajib diikuti oleh penganutnya. Namun dalam ranah kejelasan prinsip yang pasti terdapat fleksibelitas yang menjadi ruang kreatifitas dalam memandang sesuatu terutama yang berkait dengan hak-hak perempuan. Katakan saja dalam bidang pendidikan (menuntut ilmu), perempuan sering mendapatkan porsi kedua untuk meraih pendidikan dengan alasan budaya bahwa perempuan tidak diizinkan berkiprah di dunia publik sehingga tidak terlalu mementingkan pendidikan. Demikian pula dengan paham yang mengatakan bahwa are perempuan hanya berada di seputar rumah sehingga tidaklah penting baginya untuk mendapatkan pendidikan yang leih baik dan tinggi.

Tulisan ini bermaksud menyajikan bagaimana al qur'an memandang hak-hak perempuan sehingga stigma sosial budaya yang sering dilekatkan pada agama dapat direpahami. Perempuan sebagaimana juga laki-laki memiliki jaminan untuk mendapatkan hak nya.

\section{B. PEMBAHASAN}

Berbagai literature dijelaskan bagaimana buruknya kedudukan dan hak perempuan sepanjang peradaban yang ada. Dalam peradaban Yunani misalnya perempuan tidak di anggap sebagai manusia yang utuh dengan segala hak kemanusiaannya perempuan bagi mereka tidak lain sebagai benda untuk mengurus rumah bahkan di persamakan denganbenda yang dapat di perjual belikan atau di buang begitu saja. Mereka tidak memiliki hak-hak sipil, apalagi hak waris mereka juga tidak punya hak untuk bicara, jadi peranan perempuan di masa itu hanya sebatas obyek untuk melampiaskan kebutuhan seksual kaum laki-laki. Lebih dari itu dalam pandangan mereka, dewa-dewa melakukan 
hubungan gelap degan rakyat rakyat bawahan dan dari hubungan gelap itulahirlah "Dewi Cinta" yang mereka puja (Shihab, 1996). Dengan penafsiran secara textual penulis akan menganalisa bagaimana sesungguhnya hak-hak perempuan tersebut terutama bila dikaitkan dengan hak untuk mendapatkan pendidikan, hak untuk mendapatkan mahar dan nafkah, hak minta cerai, hak waris, dan hak material.

\section{Persamaan hak Antara Laki-laki dan Perempuan dalam Al-Quran}

Secara umum tidak ada perbedaan hak antara laki-laki dan perempuan, hal ini di jelaskan dalam surat An-Nisa' ayat 32:

Artinya:

Bagi laki-laki ada hak. bagian dari apa yang diusahakannya, dan bagi perempuan ada bak/ bagian dari apa yang diusahakanya.

Ayat ini menjelaskan bahwa antara laki-laki dan perempuan tidak ada bedanya dalam apa yang diusahakannya. Perbedaan yang dijadikan ukuran untuk meninggikan dan merendahkan derajat mereka hanyalah nilai pengabdian dan ketaqwaanya kepada Allah (QS. Al-Hujurat:13). Bagi islam perempuan yang baik adalah perempuan yang menjalankan kehidupan seoptimal mungkin menurut Al- Quran dan Hadits, mampu menjalankan fungsi, hak, dan kewajibanya, baik sebagai hamba Allah. Hal ini terdapat dalam surat An-Nahl, Ayat 97:

Artinya:

Barang siapa yang mengerjakan amal soleh, baik laki-laki maupun perempuan dalam keadaan beriman, maka sesungguhnya akan kami berikan kepadanya kehidupan yang baik dan sesunggubnya akan kami beri balasan kepada mereka yang lebih baik dari apa yang telah mereka kerjakan.

Ayat ini juga menjelaskan bahwa di dalam amal shaleh dan iman itu sama kedudukanya antara laki-laki dengan perempuan. Masing-masing sama-sama sanggup menumbuhkan iman dalam hati dan berbuat amal kebaikan seoptimal mungkin. Maka tidak kurang tanggung jawab perempuan daripada laki-laki didalam menegakkan iman kepada Allah dan berbuat amal shaleh. Oleh sebab itu maka keduanya sama-sama dijanjikan Allah akan di beri kehidupan yang baik (Hayatan Thayyibah), karena laki-laki dan perempuan adalah sama di hadapan Allah, yaitu sama-sama hambaNya. Dan yang mulia diantara keduanya adalah yang lebih bertaqwa. 
Dalam hal menyiarkan agama allah atau mrnyampaikan kebenaran, allah juga tidak melarang perempuan untuk melakukannya. Perempuan sebagai juru dakwah dijelaskan Al-Quran ayat 104,110:

Artinya:

"bendaknya ada diantara kamu segolongan umat yang menyeru kepada kebaikan, menyurub kepada yang ma'ruf dan mencegah yang mungkar. Mereka itulah orang-orang yang beruntung. Kamu adalah umat yang terbaik yang dilabirkan untuk manusia, menyurub kepada yang ma'rif dan mencegah dari yang mungkar, dan beriman kepada Allah. Sekiranya abli kitab beriman, tentulah itu lebih baik bagi mereka. Diantara mereka ada yang beriman, dan kebanyakan mereka orang-orang yang fasik"”

Dalam ayat ini Allah tidak membedakan antara laki-laki dan perempuan, dengan arti kata bahwa berbuat amar ma'ruf nahi mungkar yang berlandaskan iman kepada Allah SWT adalah sama-sama menjadi kewajiban bagi semua umat muslim, tanpa ada kecualinya, sebagaimana sabda rasulullah SAW dalam kitab shahih. Muslim: Dari Abu Sa”id al-Kudari r.a., dia berkata "saya mendengar Rasulullah saw bersabda, "Barang siapa diantara kamu melihat kemungkaran maka hendaklah ia mengubahnya dengan tangan, jika tidak mampu maka hendaknya dengan lisanya, dan jika tidak mampu, maka hendaklah dengan hatinya. Ini merupakan (amalan) iman yang paling lemah" (Diriwayatkan oleh Imam Muslim)

Dalam ajaran Islam laki-laki dan perempuan adalah kewajiban menyampaikan kebenaran dan melarang dari kemungkaran hal inilah yang disebut juru dakwah, lebih-lebih lagi dalam rumah tangga dan masyarakat sekitarnya. Sebagaimana kita ketahui bahwa Siti Aisyah (Istri Rasulullah SAW) sendiri banyak meriwayatkan hadits, berarti beliau juga sebagai juru dakwah atau mubalighah. Sebagaimana diungkapkan Nabi Muhammad SAW:

Artinya:

"Ambilah setengah pengetahuan agama kalian dari Al-Huraira" (Aisyah)

Banyak lagi dalam sejarah diungkapkan, bahwa para perempuan (muslimah) yang menjadi da'iyah, mubalighah, dan mudarisah, seperti Sayyidah sakinah putri AlHusai bin Ali bin Abi Thalib, Al-Syaikhah Syuhrah yang di gelar Fakhr Al-Nisa' (kebanggan perempuan) adalah salah seorang guru Imam Syafi'I (Mahmud, 1986) dan masih banyak yang lainya. Dari segi penciptaan Quran menerangkan perempuan dan lelaki adalah sama-sama diciptakan Allah dan berada dalam derajat yang sama. Tidak ada isyarat bahwa Adam lebih tingi derajatnya dari Hawa. Sesungguhnya banyak 
contoh bahwa perempuan itu mampu dan bisa berbuat seperti kaum laki-laki dalam berusaha dan berkarya sebagaimana firman Allah yang terdapat dalam surat An-Nisa' ayat 1 yang atinya.

Artinya:

"Hai sekalian manusia, bertaqwalah kepada Tuhanmu yang telah menciptakan kamu dari jenis yang sama dan darinya Allah menciptakan pasangannya dan dari keduanya Allah memperkembang biakkan keturunan baik yang laki-laki maupun perempuan"

Demikian Al-Quran menolak pandangan-pandangan yang membeda-bedakan laki-laki dan perempuan dengan menegaskan bahwa keduanya berasal dari jenis yang sama dan bahwa dari keduanya secara sama-sama Tuhan mengembang biakkan keturunan yang baik laki-laki maupun perempuan. Dengan konsideran ini tuhan mempertegas bahwa.

Artinya:

"Sesunggubnya Allab tidak menyia-nyiakan amal orang-orang yang beramal baik laki-laki maupun perempuan” (QS. 3:195)

Atas dasar ini, dapat dikatakan bahwa setiap laki-laki maupun perempuan memiliki hak yang sama, karena tidak ditemukan satupun ketentuan dalam Al-Quran yang dapat dipahami sebagai melarang keterlibatan perempuan dalam kehidupan bermasyarakat. Realitas ini juga bisa kita temukan pada masa Nabi, Sahabat, Tabi'in, dan masa kejayaan islam bahkan sampai sekarang. Mereka tampil dalam berbagai bidang. Rasulullah sendiri begitu sayang dengan perempuan yang aktif, ini terbukti istrinya khadijah adalah seorang pengusaha dan konglomerat yang sukses dan istrinya yang lain aisyah, adalah ilmuan di bidang hadits, dan di beri kesempatan untuk ikut berjuang. Sedangkan khalifah umar ibnu Al-Khatab mengangkat Asy Syifa' (w640 M) untuk menangani pasar kota madinah.

Pada sisi lain, tampil nama seperti Ummu Salamah (istri Nabi). Shafiyah, Laila Al-Gafariyah, Ummu Sinam Al-Aslamiyah, dan lain-lain sebagai tokoh-tokoh yang terlibat dalam perperangan. Imam Bukhari sendiri dalam kitab Shahih-nya memuat bagian yang membahas tentang kegiatan kaum perempuan, seperti "Bab keterlibatan perempuan Dalam Jihad” "Bab perperangan perempuan di lautan”, "bab keterlibatan perempuan menangani korban", dan lain-lain (Shihab, 1996). Di samping itu, para perempuan pada masa Nabi SAW aktif pula pada berbagai bidang pekerjaan. Ada yang bekerja sebagai perias pengantin, seperti Ummu Salim binti Malhan, Shafiyah 
binti Huyay (Ibrahim bin Ali Al-Wazir, 1997). Tentu di zaman modern sekarang ini banyak kaum perempuan yang meniti karir di berbagai bidang profesi, bahkan menjadi presiden dan perdana mentri.

Kenyataan di atas menunjukan bahwa perempuan itu mampu berkiprah di berbagai bidang, seperti halnya lelaki. Kaum perempuan adalah saudara sekandung laki-laki, sehingga hak-haknya hampir dapat dikatakan sama. Kalau ada pembedaanya, maka itu akibat fungsi dan tugas-tugas utama yang di bebankan tuhan kepada masingmasing jenis kelamin itu, sehingga perbedaan yang ada tidak mengakibatkan yang satu merasa memiliki kelebihan atas yang lain (QS 4:32). Namun pada surat Al-Ahzab 33, hak kaum perempuan untuk berusaha di luar rumah dibatasi:

Artinya:

"Dan bendaklah kamu tetap dirumahmu dan janganlah kamu berbias dan bertingkah seperti orang-orang jabiliah dahulu".

Sepintas ayat ini membatasi kaum perempuan untuk beraktifitas di luar rumah. Memang tugas utama kaum perempuan adalah dirumah mengurus rumah tangga dan mengurus anak-anak. Namun tidak ada larangan bagi perempuan untuk suatu kepentingan dengan seizin suami, seperti di jelaskan diatas. Ayat ini hanya mengisyaratkan bahwa tugas pokok perempuan yang di emban oleh seorang istri adalah mengurus rumahtangganya.

\section{Hak Perempuan dalam Pendidikan}

Perempuan dalam statusnya sebagai anak, berhak mendapat nafkah pendidikan dan pengasuhan sampai mereka menikah. Kewajiban ini tidak hanya di perintahkan pada laki-laki saja tapi juga kepada perempuan. Hal ini dapat dipahami dari hadits Nabi yang menyebutkan,

Artinya:

"menuntut ilmu adalab kewajiban setiap muslim dan muslimab"(HR. Al-Tabrani melalui Ibn Mas'ud)

Dari hadits ini memberikan gambaran mengenai pentingnya menuntut ilmu bagi semua orang tidak hanya kaum pria tapi juga perempuan, dan dari hadits ini pula memberikan gambaran bahwa Islam tidak mendiskriminasi perempuan dalam menuntut ilmu, seperti banyak tudingan yang dilontarkan golongan tertentu. Dalam surat al-Mujadalah ayat 11 allah juga menjelaskan betapa pentingnya menuntut ilmu. 
Artinya:

"Allah akan meninggikan orang-orang yang beriman di antaramu dan orang-orang yang diberi ilmu pengetabuan beberapa derajat”. (QS. 58:11)

Setiap manusia memiliki hak untuk menuntut ilmu. Tidak hanya bagi laki-laki, demikian juga perempuan bebas dalam menuntut ilmu. Apabila perempuan tidak bersuami, maka dia bisa mencari ilmu dan tidak seorangpun boleh mencegahnya untuk belajar. Namun apabila dia sudah menikah, maka untuk melanjutkan pendidikan dia harus bermusyawarah dan saling memahami dengan suaminya (Amini, 2007). Kewajiban bagi perempuan untuk menuntut ilmu terkait juga dengan tanggung jawab seorang perempuan sebagai ibu, dimana dalam pendidikan pertama yang diterima oleh seorang anak adalah dari orang tua, terutama ibunya. Jika perempuan tidak memiliki ilmu yang cukup untuk mendidik anak-anaknya, maka hal ini akan terlihat pada lemahnya perkembangan ilmu pengetahuan generasi penerusnya. Begitu juga sebaliknya Jika perempuan memiliki ilmu pengetahuan yang luas untuk mendidik anak-anaknya, maka perkembangan ilmu pengetahuan generasi penerusnya akan semakin maju.

Al-Quran sendiri memberikan pujian kepada ulul albab, yang berfikir dan memikirkan kejadian langit dan bumi. Para ulul albab itu tentunya kaum lelaki dan perempuan, hal ini bisa dipahami dari lanjutan ayat ketika Tuhan menjelaskan tentang sifat-sifat para ulul albab. Allah mengatakan.

Artinya:

"Maka Tuhan mereka mengabulkan permohonan mereka dengan berfirman, sesungguhnya aku tidak akan menyia-nyiakan amal orang-orang yang beramal diantara kamu, baik lelaki maupun perempuan.....” (QS. Ali Imran, 3:195).

Ayat ini menjelaskan bahwa kaum perempuan dapat berfikir, mempelajari kemudian mengamalkan apa yang mereka hayati dari zikir kepada Allah serta apa yang mereka ketahui dari alam raya ini, sehingga menimbulkan berbagai macam disiplin ilmu. Dan mereka bebas untuk mempelajari apasaja, sesuai dengan keinginan dan kecendrungan masing-masing. Sejarah telah menukilkan bahwa banyak perempuan di zaman Nabi SAW menyadari benar kewajiban ini, sehingga mereka memohon kepada Nabi SAW agar beliau bersedia menyisihkan waktu tertentu dan khusus untuk mereka menuntut berbagai ilmu dari nabi SAW. Al-Muqarri dalam bukunya Nafhu Al-Thib, bahwa Ibnu Mutharraf, seorang pakar bahasa pada 
masanya, pernah mengajar sesorang perempuan tentang bahasa arab. Sehingga perempuan itu pada akhirnya memiliki kemampuan melebihi gurunya sendiri, khususnya dalam bidang puisi, sampai ia di kenal dengan nama Al-'arudiyat karna keahlianya dalam bidang ini.

\section{Hak Perempuan Mendapatkan Mahar dan Nafkah}

Di dalam perkawinan, perempuan ditempatkan pada kedudukan yang terhormat. Dia diperlakukan sebagai manusia yang mempunyai hak-hak yang sempurna. Dia harus dilamar secara layak dari wali atau keluarga nya. Tanpa persetujuan anak gadis tersebut sang ayah dilarang mengawinkannya dengan paksa. Dia dan laki-laki peminangnya dapat saling melihat, sehingga masing-masing dapat saling mengenal, dimintai pendapat atau persetujuannya dan persetujuan atas lamaran yang ditujukan kepadanya. Atas persetujuannya dan persetujuan wali atau keluarganya, serta pria pelamar, dilaksanakan akad nikah dengan memberikan mahar kepada wanita oleh pihak lelaki.

"Berikanlah maskawin (mahar) kepada wanita yang kamu nikahi sebagai pemberian dengan kerelaan”. (QS.4:4)

"Bayarlah kepada mereka maharnya (dengan sempurna), sebagai suatu kewajiban" (QS.

Mahar itu tidak boleh di usik sedikitpun tanpa izin oleh pihak istri. Islam mewajibkan mahar atas suami dan tidak mewajibkan atas istri, karena mempertimbangkan tabiat penciptaanya masing masing. Laki-laki diberikan kelebihan fisik dan kelebihan lainya, sehingga kepadanya diberikan tanggung jawab member nafkahtermasuk juga mahar. Tugas member mahar merupakan lambing perlindungan dan kasih sayang kepada perempuan, agar dia tidak memeprtaruhkan kehormatanya sekedar mendapatkan harta benda, atau mau menikah karena mempertimbangkan mahar tersebut, seakan-akan mahar itu lah yang ia cari.

Mahar yang diberikan saat akad nikah, menjadihak istri secara murni dan menjadi miliknya. Tidak seorangpun dari para walinya untuk ikut berserikat dengan maharnya, apalagi menguasai an memepergunakannya. Lebih lanjut dia berham menjual, menghibahkan, mengsedekahkan atau meminjamkanya. Apabila istri meninggal atau becerai, sebelum dia mendapatka hak maharnya, baik keseluruhanya atau sebahagianya, maka itu merupakan harta warisan bagi istri dan menjadi hutang 
bagi si suami dan wajib di lunasi. Demikian juga bila yang meninggal itu suami, maka mahar tersebut tetap menjadi hutang yang harus dilunasi.

Setelah pernikahan suami berkewajiban member nafkah kepada istrinya.

"dan kewajiban ayah member makan dan pakaian kepada para ibu dengan cara yang ma'ruf” (QS.2:233)

Nafkah yang dimaksud adalah untk memenuhi kebutuhan sandang, pangan, pakaian, tempta tinggal, pengobatan dan kebutuhan rumah tangga lainya. Besarnya jumlah nafkah ini sangat bergantung dengan kemapuan suami.

"Allah tidak memikulkan beban pada seseorang melainkan sekedar apa yang Allab berika kepadanya. Allah kelak akan member kelapangan sesudah kesempitan "(QS. AlTalaq, 65:7)

Hal ini juga ditegaskan oleh Hadits Nabi :

"Dan hak mereka atas dirimu (suami) ialah kamu member makan dan pakaian kepada mereka dengan cara yang ma'ruf" (HR. Muslim dan Abu Daud)

Keharusan suami member nafkah kepada istrinya berlaku dalam keadaan apapun, seperti dijelaskan dalam ayat diatas. Hal ini menunjukan bahwa pemberian nafkah itu wajib dalam keadaan apapun dan tidak bisa dihindari. Istri tidak wajib menafkahi dirinya sendiri dan mengambil dari hartanya bila dia kaya, kecuali dia melakukan dengan senang hati. Islam membebankan nafkah ini kepada laki-laki, karena dia menjadi pemimpin rumah tangga dan segala hal yang ada di dalamnya. Hal ini jelas bahwa kaum laki-laki adalah pemimpin dalam rumah tangganya, sehingga ia bertanggung jawab memenuhi segala kebutuhan rumah tangganya seperti, makan, pakaian, tempat tinggal kesehatan, dan lain-lainya, sesuai dengan kemampuanya.

\section{Hak Perempuan Untuk Minta Cerai}

Perceraian dalam istilah fiqh disebut "Talak" atau "Furqah". Adapun arti dari talak adalah melepas ikatan atau membatalkan perjanjian. Sedangkan Furqah artinya bercerai atau lawan dari berkumpul, kemudian kedua kata itu dipakai oleh para ahli fiqh sebagai satu istilah yang berarti perceraian antara suami dan istri (Soemiyati, 1986). Pasangan suami istri selalu mendambakan hidup yang harmonis, tenteram, damai, ceria dan bahagia. Hal ini sesuai dengan tujuan pernikahan yang disyari'at dalam islam untuk membentuk keluarga sakinah, mawaddah, dan warahmah. Namun dalam kehidupan rumah tangga, perselisihan adalah suatu yang tidak dapat dihindari. 
Dalam kehidupan rumah tangga yang sulit untuk mempertahankan kebersamaan, kedua belah pihak boleh memikirkan alternatif untuk mengakhiri hubungan sebagai suami istri. Hukum talak pada dasarnya adalah sesuatu yang dibenci oleh Allah SWT dan tidak diharapkan oleh semua orang, akan tetapi talak dibolehkan dalam islam. Sebagaimana Rasullullah SAW bersabda:

Artinya:

Perceraian bukanlah sesuatu yang diharamkan dalam Islam, kendatipun tidak disukai oleh Allah SWT.(HR Abu Dawud).

Al-Quran menuntun bila terjadi percekcokan maka hendaklah mereka saling bersabar. Boleh jadi kamu tidak menyukai salah satu sifatnya, tetapi Allah telah menjadikan baginya kebaikan yang banyak (QS. 4:19) Bila upaya ini belum bisa mengatasi persoalan, maka langkah selanjutnya adalah memberi nasehat kepada sang istri, kemudian dengan pisah tempat tidur, dan selanjutnya baru boleh memukulnya (QS.4.34). Selanjutnya mencari perdamaian adalah sangat dianjurkan dan perdamaian itu lebih baik bagi keduanya (QS. 4:128).

Dapat dipahami bahwa pelaksanaan perceraian harus berdasarikan alasan yang kuat, dan merupakan jalan teakhir yang ditempuh oleh suami istri. Apabila telah melalui tahapan-tahapan perbaikan yang dilakukan sendiri oleh masing-masing suami istri, keluarga, sampai ke Pangadilan, akan tetapi tetap tidak ada harapan untuk memperbaiki dan meneruskan ikatan perkawinan atau mengembalikan keutuhan hidup rumah tangga, maka Allah SWT menyediakan sebuah solusi ini dapat dibenarkan apabila dalam keadaan terpaksa dan dengan memenuhi beberapa persyaratan tertentu (Bagir, 2002).

Bila keadaan sudah diambang krisis, maka keduanya boleh mengutus wakilnya untuk menengahi persoalan. Kepada kedua hakam inilah diserahkan, apakah akan melanjutkan atau memutuskan ikatan yang sudah ada.

Artinya:

"jika keduanya bukumi itu bermaksud mengadakan kebaikan, niscaya Alab memberi taufiq kepada keduanya (QS. 4:35)

Artinya:

"jika keduanya bercerai, maka Allah akan memberi kecukupan kepada masing-masing dari limpahan karuniaNya QS. 4:130) 
Jadi, perceraian dianggap sebagai jalan terakhir, yang tidak bisa dilaksanakan, kecuali kalau memang permasalahanya benar-benar memuncak dan tidak ada cara lain yang bisa di tempuh. Syariat Islam juga tidak meremehkan sisi kepentingan perempuan dan haknya untuk menentukan perceraian. Meskipun hak cerai ada di tangan suami, namun Islam juga memberikan hak kepada perempuan untuk menentukan perceraian, jika terpenuhi syarat-syarat yang sudah di tentukan perceraian. Biasanya sang istri melepaskan sebagian haknya kepada suami atau memberinya sejumlah harta benda telah di sepakati oleh keduanya, hal inilah yang disebut Al-Khulu', atau perceraian dengan memberikan tebusan. Hal ini terjadi mana kala istri melihat suatu alasan yang tepat untuk mengakhiri hidup berdampingan bersama suaminya, dan jika tetap bertahan dikhawatirkan akan melanggar ketentuanketentuan yang ditetapkan agama. Inilah yang diterangkan Allah adalah (QS. 2.229)

Artinya:

"jika kamu khawatir bahwa suami istri tidak dapat menjalankan bukum-bukum Allah, maka tidak ada dosa atas keduanya tentang bayaran yang diberikan oleh istri untuk menebus dirinya".

Hal ini bisa dilakukan bila suami tidak memberi nafkah, ada aib pada suaminya, diperlakukan dengan kasar dan buruk, menyiksanya ataupun ditinggal pergi dalam waktu yang cukup lama atau alasan-alasan lainya yang dapat dibenarkan. Disamping itu juga ada hak bagi perempuan akibat perceraian, yaitu untuk mendapatkan nafkah dan tempat tinggal selama masa iddah. Setelah suami menceraikan istrinya, ia tetap bertanggung jawab memberikan nafkah kepada mantan istrinya selama masa iddahnya. Apabila masa iddah nya telah habis, mantan istrinya itu mempunyai hak untuk kawin lagi dengan mantan suaminya atau dengan orang lain (QS. 2:232 dan 234), dan juga ia punya hak untuk menyusui dan mendidik anak-anaknya.

\section{Hak Perempuan Dalam Bidang Kewarisan}

Islam mengatur hak baik laki-laki maupun perempuan dalam hak waris. Aturan membagi harta antara ahli waris dalam islam merupakan bentuk manifestasi dari pengakuan islam tentang adanya hak milik perseorangan, baik terhadap harta bergerak, maupun terhadap harta tidak bergerak, dan juga manifestasi bahwa harta milik seseorang setelah ia mati, berpindah kepada ahli waris dan harus dibagi secara adil antara ahli warisnya, baik kepada perempuan ataupun laki-laki, baik kecil maupun besar apabila telah terpenuhi syarat-syarat menerima harta warisan (Hasbi al- 
Shiddieqy, 1973). Dalam hukum Kewarisan Islam, asas keadilan mengandung pengertian adanya keseimbangan antara hak yang diperoleh dan harta warisan dengan kewajiban atau beban kehidupan yang harus ditanggungnya atau ditunaikannya di antara para ahli waris (Zahari, 2003). Oleh karena itu, arti keadilan dalam hukum waris Islam bukan diukur dari kesamaan tingkatan antara ahli waris, tetapi ditentukan berdasarkan besar-kecilnya beban atau tanggung jawab diembankan kepada mereka, ditinjau dari keumuman keadaan atau kehidupan manusia.

Di bidang kewarisan perempuan dalam kedudukannya dengan laki-laki, samasama berhak mendapatkan kewarisan (QS.4:7,11-12). Bagian laki-laki dua kali saudara dua kali bagian perempuan, suami menerima dua kali bagian istri, (QS. 4:11-12,176). Anak yang dalam kandungan berhak mendapatkan warisan. Dalam hukum keluarga modern, ahli waris zawil arbam telah di berikan berdasarkan wasiat wajibah seperti di Mesir dan juga di Indonesia. Pembagian kewarisan terkait ayat diatas yaitu laki-laki mendapat 2 bagian bila dibanding dengan perempuan (2:1). Hal tersebut bersifat rasional, karena ada unsur kebenaran dan keadilan jika dikaitkan dengan ketentuan tentang hak dan kewajiban suami-istri dalam hukum perkawinan dan kewajiban seorang anak laki-laki dalam pengurusan dan pemeliharaan orang tuanya setelah berumah tangga.

Sistem yang ditawarkan Islam ini merupakan konsepsi yang baru, menyalahi sistem kewarisan pra Islam. Yang berhak mewarisi bukan hanya laki-laki, tetapi kaum perempuanya, yang pada sebelumnya justru sebagai yang bisa diwarisi. Dari harta warisan menjadi ahli waris. Bagian-bagian yan sudah ditentukan itu merupakan hak milik masing-masingnya secara mutlak. Dalam KHI pasal 176 : Anak perempuan bila hanya ia seorang mendapat separoh bagian, bila dua orang atau lebih mereka bersama-sama mendapat dua pertiga bagian, dan apabila anak perempuan bersamasama anak laki-laki, maka bagian anak laki-laki adalah dua banding satu dengan anak perempuan (Departemen agama R.I, 1998). Islam juga menjadikan atas keadilan berimbang sebagai dasar kewarisannya. Bagian laki-laki dua kali bagian perempuan, karena hal ini dikaitkan dengan tugas dan tanggung jawab masing-masing. Laki-laki mendapatkan bagian yang lebih besar, karena kepadanya diberikan tanggung jawab memberikan mas kawin dan nafkah. 


\section{Hak Perempuan Untuk Memiliki Harta}

Islam memperbolehkan perempuan memiliki sendiri berbagai jenis harta, entah berupa mata uang, pekarangan tempat tinggal, harta bergerak dan tidak bergerak lainya. Islam memperbolehkan memiliki semua itu, dan dia mandiri memilikinya, terlepas dari campur tangan suami dan orang lain. islam juga memperbolehkan bagi perempuan untuk mengembangkan harta dengan berbagai cara yang dibolehkan, yang bisa dia urus sendiri atau diserahkan kepada orang lain untuk mengurusnya.

Perempuan juga mempunyai hak yang utuh untuk membelanjakan hartanya jika sudah baligh dan mampu mengurusnya, baik dengan jual beli, pinjam-meminjam, pemberian sedekah, wakaf, wasiat dan cara-cara pengeluaran lainya yang dibolehkan syariat. Dia juga mempunyai kebebasan dan kemerdekaan yang utuh untuk semua itu, baik dia sebagai anak gadis atau sebagai istri. Bapak atau suami atau kerabatnya tidak boleh ikut campur dalam harta miliknya, kecuali dengan kerelaanya.

Bagitu juga hak perempuan dalam harta warisan, pada masa sebelum Islam (Jahilliah), mereka tidak memperoleh sedikitpun harta warisan, bahkan mereka disamakan dengan harta warisan yang bisa diwariskan. Namun Islam memberikan hak ini kepada perempuan. Hak mendapatkan harta warisan yang sudah ditentukan itu menjadi miliknya secara individual, bukan milik kolektif. Selanjutnya dia bebas meman-faatkannya. Dia juga diberi wewenang untuk mempertahankan hak miliknya dihadapan hakim, sementara itu suaminya tetap berkewajiban memberinya nafkah. Islam juga tidak membedakan antara perempuan dan laki-laki dalam masalah banyak sedikitnya hak-hak material, kecuali dalam penetapan harta warisan, sebagai warisan, sebagai mana terdapat dalam Al-Quran surat Al-Nisa' ayat 11.

Artinya:

"Allah mensyaria'tkan bagimu tentang (pembagian pusaka) untuk anak-anakmu, yaitu bagian seorang anak. laki-laki sama dengan bagian dua orang anak perempuan. Jika semua anak itu perempuan lebih dari dua orang, maka bagi mereka dua pertiga harta yang ditinggalkan. Jika anak perempuan itu seorang saja, maka memperoleh separoh harta itu"

Ketentuan pembagian ini bukan berarti sikap pilihkasih berdasarkan jenis kelamin. Akan tetapi, ketentuan ini justru menunjukan keseimbangan dan keadilan, karena bedanya beban tanggung jawab antara laki-laki dan perempuan dalam kehidupan keluarga dan dalam sistem sosial Islam. Oleh karena itu, tampaklah keadilan dan keserasian antara beban dan tanggung jawab dan perolehanya dalam pembagian warisan yang bijaksana ini. Sedangkan selain warisan tidak ada perbedaan 
antara keduanya, tidak pula dalam upah kerja. Berbeda dengan keadaan dunia barat dan negara manapun pada masa ini yang relatif memberikan upah yang lebih sedikit kepada perempuan daripada laki-laki.

Jadi, dalam Islam hak perempuan dan laki-laki tidak dipandang identik atau sama. Tetapi, Islam pernah menganut pengutamaan dan deskriminasi yang menguntungkan laki-laki dan merugikan perempuan. Islam juga menggariskan prinsip persamaan antara laki-laki dan perempuan. Tetapi Islam tidak mengidentikan hak-hak keduanya. Kalaupun ada perbedaan itu adalah akibat fungsi dan tugas-tugas utama yang dibebankan agama kepada masing-masing jenis kelamin yang mengakibatkan satu sama lainnya saling bantu membantu dan saling melengkapi dalam hidup dan kehidupan.

\section{SIMPULAN}

Islam begitu memuliakan perempuan dengan melihatnya sebagai mahluk yang utuh, dengan martabat agung dengan dimensi yang tak terhingga, dengan perempuan tidak dinilai dari segi keindahan tubuhnya kemolekan parasnya, kesupelan pergaulannya. Jauh lebih luas dari itu, perempuan dalam Islam juga dilihat sebagai manusia yang seperti juga laki-laki, punya tugas-tugas kemanusiaan, tanggung jawab pribadi dan sosial. Mereka punya otak untuk berfikir, nurani untuk mengambil keputusan, tangan untuk bekerja dan berkarya dan seterusnya. Semua potensi kemanusiaan yang diberikan kepada lakilaki juga diberikan kepada perempuan. Karenanya tidak ada perbedaan hak-hak mereka di bidang pendidikan, sosial dan lain-lainnya dalam Al-Quran. Kalaupun ada perbedaan itu adalah akibat fungsi dan tugas-tugas utama yang dibebankan agama kepada masingmasing jenis kelamin yang mengakibatkan suatu sama lainnya saling bantu membantu dan saling melengkapi dalam hidup dan kehidupan.

Dalam islam perempuan juga mempunyai hak sebagaimana kaum laki-laki, namun pada hal-hal tertentu ada yang tidak sama, hal ini disebabkan fungsi dan tugas utama yang diemban kaum laki-laki. Diantara hak-hak perempuan itu adalah: hak mendapatkan pendidikan, hak mendapatkan mahar dan nafkah, hak minta cerai apabila telah cukup syarat-syaratnya dan kalau diteruskan akan menimbulkan kemudharatan, hak dalam bidang kewarisan dan hak materi. 


\section{DAFTAR REFERENSI}

Ibrahim bin Ali Al-Wazir, 'ala Masyarif Al-Quran Al-Khamis 'Asyar, Kairo, Dar Al-Syuruq.

Jamaluddin Muhammad Mahmud, Huquq al-Mar'at Al-Mujtama' Al-Islam, Kairo, Kairo Al-Haiat Al Mishriyat Al-Amat, 1986.

Quraish Shihab, Wawasan Al-Quran Tafsir Maudbu'I atas Pelbagai Persoalan Umat, Mizan, Bandung, Cet, I, 1996.

Sayyid Qutb. Fi Zhilal Al-Quran, Penerjemah As'ad yasin, Abdul Aziz Salim Basyarahil, Muchtob Hamzah, Jakarta, Gema Insani, Jilid I, 2000.

Universitas Islam Indonesia, Al-Quran dan Tafsirnya, Jogjakarta, PT. Dana Bhakti Wakaf, jilid II, 1995. 